\title{
Removal of heavy metals by chitin: equilibrium, kinetic and thermodynamic studies
}

\author{
Wassila Boulaiche ${ }^{1} \cdot$ Boualem Hamdi $^{1,2} \cdot$ Mohamed Trari $^{3}$
}

Received: 31 May 2018 / Accepted: 7 March 2019 / Published online: 14 March 2019

(C) The Author(s) 2019

\begin{abstract}
Adsorption is one of the most commonly used methods for the wastewaters treatment. In this work, we studied the impact of experimental conditions on the adsorption of heavy metals $\mathrm{M}(\mathrm{II})(\mathrm{M}=\mathrm{Cd}, \mathrm{Ni}, \mathrm{Cu}, \mathrm{Pb}$ and $\mathrm{Zn})$ in batch system using chitin obtained from crab shells. This biomaterial is selected because of its low cost, availability and efficiency. The M(II) adsorption was found to be dependent on the initial $\mathrm{pH}$, contact time, initial concentration of $\mathrm{M}(\mathrm{II})$ and biomass dose. The kinetic models of Elovich, pseudo-first-order and pseudo-second-order kinetic models were successfully applied, providing the best fitting of the experimental data. The Langmuir, Freundlich, Temkin and Dubinin-Radushkevich isotherms and the thermodynamic parameters were also discussed. The adsorption capacity peaks at: 50, 47.61, 43.4, 40 and $38.46\left(\mathrm{mg} \mathrm{L}^{-1}\right)$ for $\mathrm{Pb}(\mathrm{II}), \mathrm{Cu}(\mathrm{II}), \mathrm{Ni}(\mathrm{II}), \mathrm{Cd}(\mathrm{II})$ and $\mathrm{Zn}(\mathrm{II})$, respectively. The negative free energy $\left(\Delta G^{\circ}\right)$ and positive enthalpy $\left(\Delta H^{\circ}\right)$ indicated spontaneous and endothermic adsorption.
\end{abstract}

Keywords Adsorption $\cdot$ Heavy metals $\cdot$ Chitin $\cdot$ Kinetic $\cdot$ Isotherm

\section{Introduction}

The natural environment is constantly contaminated by various pollutants coming from industrial sectors, which in turn showed a considerable change. Toxic metals are widespread and hazardous and affect the environment with a negative impact on the ecosystem, causing dangerous diseases to both animals and humans. Among toxic metals, one can cite $\mathrm{Cd}$, $\mathrm{Hg}, \mathrm{Pb}, \mathrm{As}, \mathrm{Cr}$ and $\mathrm{Cu}$ (Salem et al. 2012) which must be removed before discharge to the aquatic environment. Unlike organic pollutants, heavy metals are refractory and cannot be degraded and accumulate in living organisms (Ali and Ateeg 2015). The elimination of metals has been the subject of several works using different techniques like ion electrodialysis (Esalah et al. 2000), sedimentation (Gupta et al. 2001), ion exchange (Da̧browski et al. 2004; Kang et al.

Mohamed Trari

mtrari@usthb.dz; solarchemistry@gmail.com

1 LEPCMAE, Faculty of Chemistry, USTHB, BP 32 El Alia, 16111 Algiers, Algeria

2 LCVRM, ENSSMAL School, BP 19 Bois des card Daly Ibrahim, 16320 Algiers, Algeria

3 LSVER Laboratory, Faculty of Chemistry, USTHB, BP 32 El Alia, 16111 Algiers, Algeria
2008), biological operations (Rashid et al. 2014), coagulation/flocculation (Yue et al. 2009), nanofiltration (Hafiane et al. 2000), solid-phase extraction (Khezami and Capart 2005), adsorption (Abolhasani and Behbahani 2015; Behbahani et al. 2014) and electrokinetic remediation (Sawada et al. 2004). However, all these techniques suffer from high costs of capital and operations as well as the elimination of metallic sludge (Malairajan 2011). On the other hand, the adsorption has become advantageous for removing toxic metals because of its environmentally friendly characteristic, efficiency and low cost. In this regard, many marine wastes were used as adsorbents for both inorganic and organic pollutants (Copat et al. 2012; Izquierdo et al. 2014; Samiey and Ashoori 2012; Vilar et al. 2008).

In this respect, chitin and derived compounds were found to be effective because of their specific characteristics that motivate their utilization for the elimination of various pollutants, including metals. The ability of chitin to remove toxic metals by adsorption has already been reported elsewhere (Jaafarzadeh et al. 2014; Karthikeyan et al. 2005; Mohan and Syed-Shafi 2013; Sofiane and Sofia 2015; Xiong 2010), but the mechanism has not been fully explained (McKay et al. 1999; Volesky 1990). The use of the mass transfer models developed by Fulazzaky et al. $(2011,2013,2015)$ for the determination of external, 
internal and global mass transfer factors can allow us to better understand the adsorption mechanism.

The present study is devoted to the adsorption of metals $\mathrm{M}(\mathrm{II})(\mathrm{M}=\mathrm{Pb}, \mathrm{Ni}, \mathrm{Zn}, \mathrm{Cu}$, and $\mathrm{Cd})$ onto chitin obtained from the crabs shells. The optimization of the operating conditions (initial $\mathrm{pH}$ value, reaction time, $\mathrm{M}$ (II) concentration and biosorbent dose) in batch system allow an elimination percentage of $90 \%$. The Langmuir, Freundlich, Temkin and Dubinin-Radushkevich adsorption isotherm were applied to the experimental data to get information on the interaction $\mathrm{M}(\mathrm{II}) /$ chitin. Furthermore, the kinetic of M(II) adsorption has been studied by the pseudo-firstorder, pseudo-second-order and Elovich models.

\section{Materials and method}

\section{Adsorbent}

The chitin was obtained from the crab shells. In order to study the mechanism of $\mathrm{M}$ (II) adsorption, it is crucial to determine the chemical composition of the biomass as well as its surface morphology. The BET specific area provides information on the morphological structure of the chitin, and it was determined by adsorption-desorption isotherms of $\mathrm{N}_{2}$ at $77 \mathrm{~K}$ using a Micromeritics ASAP 2010 apparatus. The infrared spectroscopy was carried out by the Fourier transform infrared spectrometer type Nicolet 560 FTIR, in the range (4000-400 $\left.\mathrm{cm}^{-1}\right)$. The scanning electronic microscopy (SEM), used to examine the morphological structure of chitin and to visualize its surface morphology, was carried out on a Jeol-JSM-6360LV microscope. The electrolyte addition method was used for determine the point of zero charge (PZC): $0.1 \mathrm{~g}$ of chitin was immersed in $50 \mathrm{~mL}$ of $\mathrm{KNO}_{3}(0.05 \mathrm{M})$ at various $\mathrm{pHs}$ and shaken at a constant rate for $24 \mathrm{~h}$. After decantation, the final $\mathrm{pH}$ of the suspension was measured and the difference between the initial and final $\mathrm{pHs}$ was plotted against initial pH (Pagnanelli et al. 2005).

\section{Adsorbate}

Stock solutions of $1000 \mathrm{mg} \mathrm{L}^{-1}$ of $\mathrm{M}(\mathrm{II})$ with which the experiments were conducted was prepared by dissolving amounts of nitrate salts of: $\mathrm{Cd}\left(\mathrm{NO}_{3}\right)_{2}, \mathrm{Cu}\left(\mathrm{NO}_{3}\right)_{2}$, $\mathrm{Zn}\left(\mathrm{NO}_{3}\right)_{2}, \mathrm{~Pb}\left(\mathrm{NO}_{3}\right)_{2}$ and $\mathrm{Ni}\left(\mathrm{NO}_{3}\right)_{2}$, all of purity greater than $99 \%$ in distilled water, and other concentrations were prepared from the stock solution by dilution. The solutions of $\mathrm{HCl}$ and $\mathrm{NaOH}(1 \mathrm{~N})$ were used for the adjustment of $\mathrm{pH}$, monitored by a calibrated $\mathrm{pH}$ meter (HANNA instruments type).

\section{Analysis}

The experimental tests were conducted in batch mode. The residual $\mathrm{M}$ (II) concentrations were measured by atomic adsorption spectroscopy (Perkin Elmer 3030). The concentration was deduced from a calibrated graph.

\section{Adsorption experiment and equilibrium study}

Batch studies were realized with different M(II) concentrations. The $\mathrm{M}$ (II) removal was examined separately by changing the contact time, initial $\mathrm{pH}, \mathrm{M}(\mathrm{II})$ concentration and chitin dose, in order to know the equilibrium time and effect of the contact time on the mechanism of M(II) adsorption onto chitin. $0.1 \mathrm{~g}$ of the biomass was added to 50-mL conical flasks containing M(II). The flasks were shacked in the water bath (30-180 min) using a shaking water bath (Memmert) to agitate the solutions.

The $\mathrm{pH}$ effect was investigated in the region (2-8), while the $\mathrm{M}(\mathrm{II})$ concentration was studied in the range (30-400 $\mathrm{mg} \mathrm{L}^{-1}$ ) under optimal values of $\mathrm{pH}$ and contact time. The dose effect of the biosorbent varied from 1 to $10 \mathrm{~g} \mathrm{~L}^{-1}$ under fixed other parameters; the solutions were filtered with 41 filter paper. The amounts of M(II) adsorbed were calculated from the following equation:

$q_{\mathrm{e}}=\frac{V}{m}\left(C_{0}-C_{\mathrm{e}}\right)$

where $C_{0}$ and $C_{\mathrm{e}}$ are the initial and equilibrium concentrations of $\mathrm{M}(\mathrm{II})\left(\mathrm{mg} \mathrm{L}^{-1}\right) ; \mathrm{m}$ the amount of chitin $(\mathrm{g})$ and $\mathrm{V}$ the volume of solution (L). The efficiency percentage (R) of $\mathrm{M}(\mathrm{II})$ removal was calculated as follows:

$R=\frac{C_{0}-C_{\mathrm{e}}}{C_{0}} \times 100$

\section{Kinetic studies}

The kinetic study was undertaken to delimit the step which governs the M(II) adsorption onto the chitin. For this purpose, three models have been tested: the pseudo-firstorder, pseudo-second-order and Elovich models whose linear forms are given below:

The pseudo-first-order is given by the following relation (Chen 2015):

$\ln \left(q_{\mathrm{e}}-q_{\mathrm{t}}\right)=\ln q_{\mathrm{e}}-t k_{1}$

where $q_{\mathrm{e}}$ and $q_{\mathrm{t}}\left(\mathrm{mg} \mathrm{g}^{-1}\right)$ are the amount of $\mathrm{M}(\mathrm{II})$ adsorbed at equilibrium and time $\mathrm{t}(\mathrm{min})$, respectively, and $k_{1}$ the rate constant $\left(\mathrm{min}^{-1}\right), q_{\mathrm{e}}$ and $k_{1}$ are calculated from the slope and intercept of the linear plot $\ln \left(q_{\mathrm{e}}-q_{\mathrm{t}}\right)$ versus $t$, respectively. 
The linear form of the pseudo-second-order equation can be written as:

$\frac{t}{q_{\mathrm{t}}}=\frac{1}{q_{\mathrm{e}}^{2} k_{2}}+\frac{1}{q_{\mathrm{e}}} t$

$\mathrm{k}_{2}(\mathrm{~g} / \mathrm{mg} \min )$ is the equilibrium rate constant. The values of $q_{\mathrm{e}}$ and $k_{2}$ are deduced from the plot of $\frac{t}{q_{\mathrm{t}}}$ versus $t$.

The Elovich model has been applied satisfactorily to the chemisorption processes and can be expressed by the following relation:

$q_{\mathrm{t}}=\left(\frac{1}{b}\right) \ln (a b)+\frac{1}{b} \ln t$

$a\left(\mathrm{mg} \mathrm{g}^{-1} \mathrm{~min}^{-1}\right)$ is the initial adsorption rate and $b\left(\mathrm{~g} \mathrm{mg}^{-1}\right)$ the desorption constant related to the extent of the surface coverage and activation energy for the chemisorption (Madala et al. 2017). This equation is often validated for systems where the surface of the adsorbent is heterogeneous. The parameters $(1 / b)$ and $(1 / b) \ln (a b)$ are obtained from the slope and intercept of the linear plot of $q_{\mathrm{t}}$ versus $\ln (t)$, respectively.

\section{Isotherm studies}

The adsorption isotherm is important to describe how the solute interacts with the adsorbent, and four models have been used: Langmuir, Freundlich, Temkin and Dubinin-Radushkevich (D-R).

\section{Langmuir isotherm}

The model assumes a monolayer adsorption on a uniform surface. When a site is filled, no additional adsorption occurs (Behbahani et al. 2015), and the linear form is given by:

$\frac{C_{\mathrm{e}}}{q_{\mathrm{e}}}=\frac{1}{q_{\max } K_{\mathrm{L}}}+\frac{C_{\mathrm{e}}}{q_{\max }}$

The constant $\left(K_{\mathrm{L}}\right)$, related to the adsorption energy, and the maximum adsorption capacity $\left(q_{\max } \mathrm{mg} / \mathrm{g}\right)$ are calculated from the slope and intercept of the linear plot of $C_{\mathrm{e}} / q_{\mathrm{e}}$ versus $C_{\mathrm{e}}$, respectively.

\section{Freundlich isotherm}

This model describes systems where the adsorption is done on heterogeneous surfaces with interactions between the adsorbed molecules; the linear form is given by:

$\log q_{\mathrm{e}}=\log K_{\mathrm{F}}+\frac{1}{n} \log C_{\mathrm{e}}$
The constant $\left(K_{\mathrm{F}}\right)$, due to the bond energy, and the heterogeneity factor $(1 / n)$ which measures the deviation from the linear part are determined from the plot $\log q_{\mathrm{e}}$ versus $\log C_{\mathrm{e}}$.

\section{Temkin isotherm}

The model is based on a uniform distribution of the binding energies which takes into account the indirect interaction adsorbate/molecules. Moreover, the model assumes that the adsorption heat of molecules in the layer decreases linearly with the coating due to adsorbent-adsorbate interactions (Erhayem et al. 2015). The linear form is given by:

$q_{\mathrm{e}}=R T \ln K_{\mathrm{T}}+\frac{R T}{b_{\mathrm{r}}} \ln C_{\mathrm{e}}$

where the constant $b_{\mathrm{r}}$ is due to the adsorption heat $\left(\mathrm{J} \mathrm{mol}^{-1}\right)$ and $K_{\mathrm{T}}$ the isotherm constant ( $\left.\mathrm{L} / \mathrm{g}\right)$, obtained from the plot $q_{\mathrm{e}}$ versus $\ln C_{\mathrm{e}}$ (Table 1$)$.

\section{Dubinin-Radushkevich (D-R) isotherm}

The $\mathrm{D}-\mathrm{R}$ model is applicable for physical processes, where the adsorption follows a mechanism of pores filling. The isotherm suggests that the adsorption has a multilayer character of Van der Waals interactions whose linear form (Hutson and Yang 1997) is expressed as:

$\ln q_{\mathrm{e}}=\ln q_{(\mathrm{D}-\mathrm{R})}-\beta \varepsilon^{2}$

where $q_{\mathrm{D}-\mathrm{R}}$ is the D-R constant (mg/g), $\beta$ the constant related to free energy and $\varepsilon$ the Polanyi potential which is defined as:

$\varepsilon=R T \ln \left(1+\frac{1}{C_{\mathrm{e}}}\right)$

The mean adsorption energy $E\left(\mathrm{~kJ} \mathrm{~mol}^{-1}\right)$ is calculated from the relation:

$E=\frac{1}{\sqrt{2 \beta}}$

This parameter gives information about the physical or chemical adsorption, an ion-exchange mechanism. The magnitude of $E\left(<8 \mathrm{~kJ} \mathrm{~mol}^{-1}\right)$ indicates that the adsorption is

Table 1 Physicochemical characteristics of chitin

\begin{tabular}{ll}
\hline Parameters & Values \\
\hline $\mathrm{pH}_{\mathrm{PZC}}$ & 7.7 \\
Specific surface area $\left(\mathrm{m}^{2} \mathrm{~g}^{-1}\right)$ & 4.35 \\
Average particle diameter $(\mu \mathrm{m})$ & 160 \\
Ash $(\%)$ & 0.8 \\
\hline
\end{tabular}


of physical nature, while values between 8 and $16 \mathrm{~kJ} \mathrm{~mol}^{-1}$ indicate a chemical adsorption by ion-exchange mechanism (Deng et al. 2009; Özcan et al. 2005; Sarı and Tuzen 2008).

\section{Thermodynamic studies}

The thermodynamic study was undertaken for the determination of the parameters $\left(\Delta G^{\circ}, \Delta H^{\circ}\right.$ and $\left.\Delta S^{\circ}\right)$ (Bouberka et al. 2005):

$\Delta G^{\circ}=-R T \ln K$

$K$ is the equilibrium adsorption constant of the isotherms (Lima et al. 2015; Liu and Liu 2008), the Temkin constant $K$ $\left(=K_{\mathrm{T}}\right)$ determined from Eq. (8). The effect of temperature on the thermodynamic constant is determined by the relation:

$\ln K=\frac{\Delta S^{\circ}}{R}-\frac{\Delta H^{\circ}}{R T}$

the thermodynamic functions $\Delta H^{\circ}$ and $\Delta S^{\circ}$ are calculated from the slope and intercept of the linear plot of $\ln K$ versus $1 / T$ while $\Delta G^{\circ}$ is given by:

$\Delta G^{\circ}=\Delta H^{\circ}-T \Delta S^{\circ}$

\section{Results and discussion}

\section{Characterization of biosorbent}

According to Muzzarelli et al. (Kumirska et al. 2010), the crab shells consist mainly of chitin, protein/carotene and calcium carbonate with an average weight composition of 25,35 and $40 \%$, respectively. The characterization showed similarities with the yield and ash content of the chitin obtained from different sources (Artemia, shrimps). $\mathrm{pH}_{\mathrm{PZC}}$ of the chitin crab is equal to 7.7, a value close to that found by previously Jaafarzadeh et al. (2015).
Table 2 FTIR analyses

\begin{tabular}{ll}
\hline$\%$ transmittance $\mathrm{cm}^{-1}$ & Interpretation \\
\hline 3440 & Elongation of $\mathrm{N}-\mathrm{H}$ and $\mathrm{O}-\mathrm{H}$ \\
2931 & $\begin{array}{l}\text { Vibrations of elongation of } \mathrm{C}-\mathrm{H} \text { bonds } \\
\text { in group } \mathrm{CH}_{2} \text { or } \mathrm{CH}_{3}\end{array}$ \\
1665 & Valence vibration $\mathrm{C}=\mathrm{O}$ (Amide I) \\
1550 & Vibration of $\mathrm{N}-\mathrm{H}$ (Amide II) \\
1379 & Vibration of $\mathrm{C}-\mathrm{H}-$ straining in group $\mathrm{CH}_{3}$ \\
1299 & Valence vibration of $\mathrm{C}-\mathrm{N}$ \\
1034 & Valance vibration of $\mathrm{C}-\mathrm{OH}$ \\
\hline
\end{tabular}

The FTIR spectroscopy allows the identification of the functional groups responsible of the M(II) adsorption; spectrum of chitin is shown in Fig. 1, and the characteristic bands and their meanings are given in Table 2.

The external morphology of chitin particles was characterized by SEM analysis. Extracted chitin particles are fiber-like and show distinctly microfibrillar crystalline structure with high diversity (Rasti et al. 2017). The micrograph illustrates the presence of "holes" on the surface that correspond to the pores present in the material. Such pores are responsible of the metals adsorption (Fig. 2).

\section{Effect of pH}

It is now well established the $\mathrm{pH}$ has a strong influence on the M(II) adsorption, because it directly affects both the surface charge and the nature of ionic species of the adsorbate. The effect on M(II) removal onto the chitin was studied in the $\mathrm{pH}$ range (2-10). Figure 3 shows that the capacity of chitin to remove metals increases with raising $\mathrm{pH}$. This can be explained as follows: at $\mathrm{pH} \sim 2$, the adsorption capacity is minimal and increases slightly with augmenting the $\mathrm{pH}(4,6,8)$. At low $\mathrm{pHs}$, the adsorbent surface is covered by $\mathrm{H}^{+}$ions, thus decreasing the
Fig. 1 Infrared spectrum of the chitin crab. Fourier transform infrared (FTIR) spectra of the chitin and their meanings are shown in Table 2

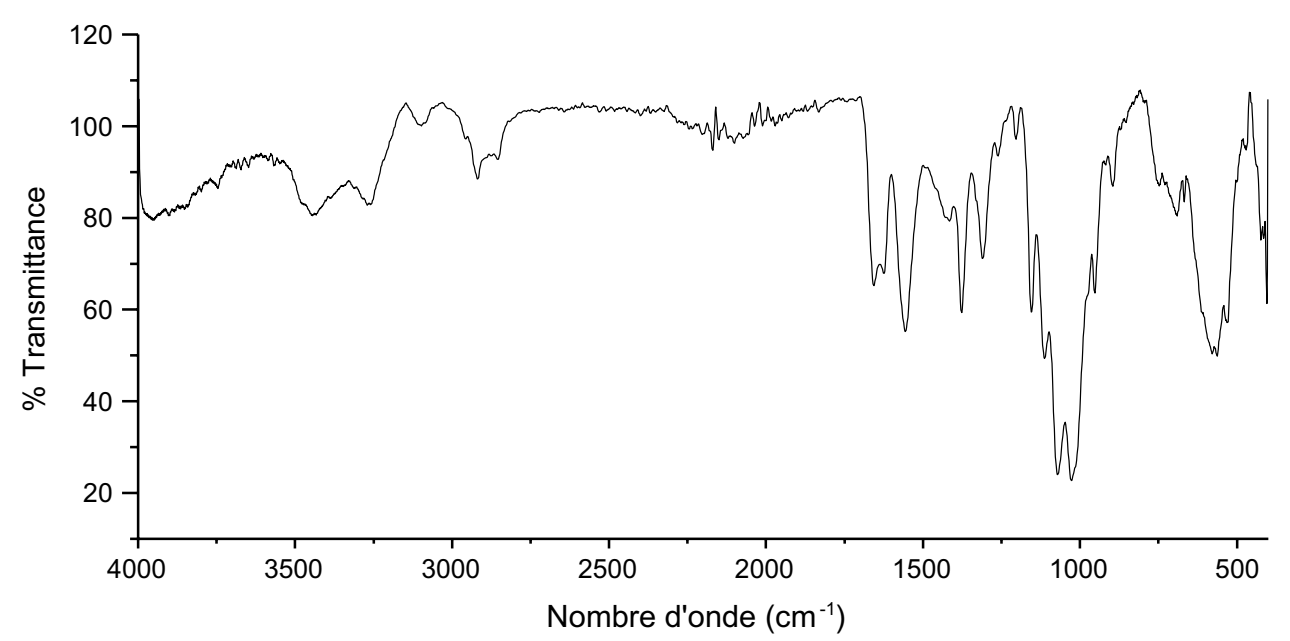



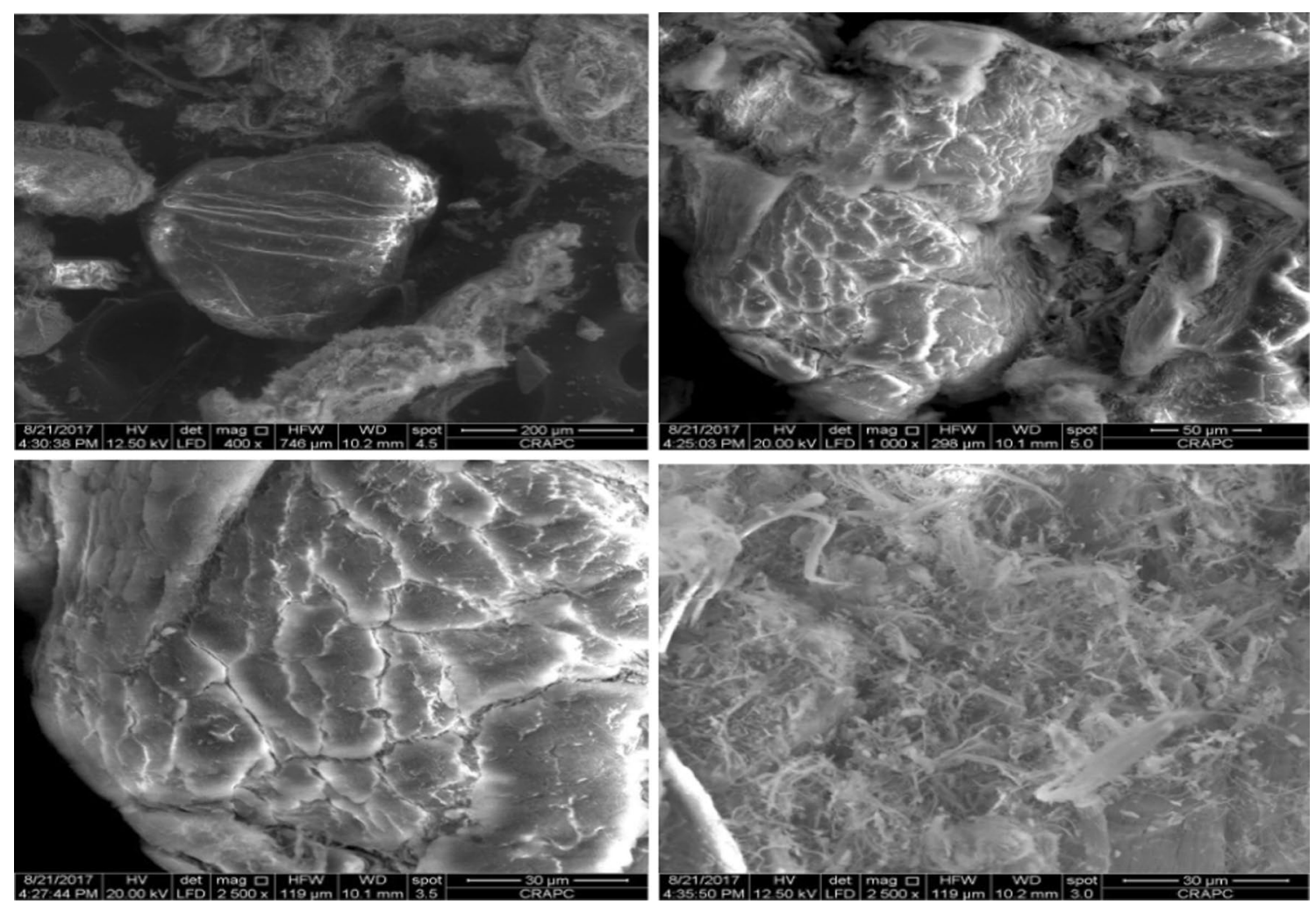

Fig. 2 SEM image of the chitin

Fig. 3 Effect of $\mathrm{pH}$ on the M(II) biosorption onto chitin

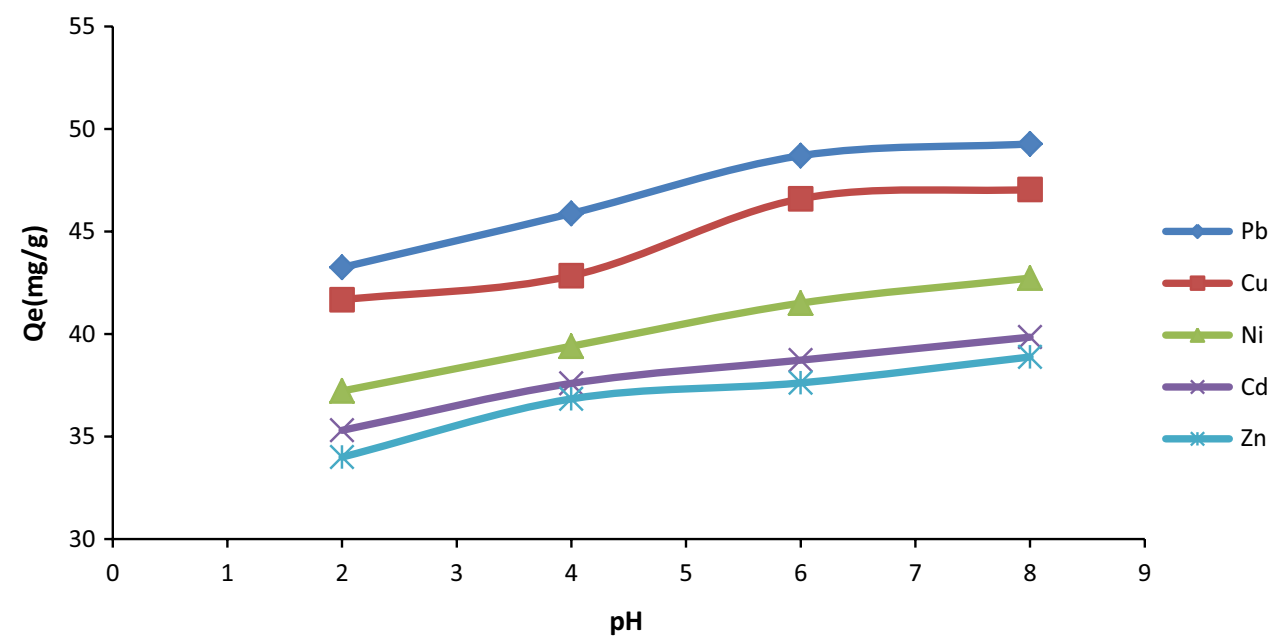

interaction $\mathrm{M}(\mathrm{II}) /$ adsorbent sites by electrostatic forces. Hence, the decrease in the adsorption rate at low pHs is due to large concentrations and high mobility of $\mathrm{H}^{+}$ions which are adsorbed more than M(II) ions (Pérez-Marín et al. 2007). With increasing $\mathrm{pH}$, the total surface area of the adsorbent becomes negative with increased liberated sites, leading to an enhanced adsorption. In the $\mathrm{pH}$ range (6-8), the metals hydroxide $\mathrm{M}(\mathrm{OH})_{2(s)}$ begins to precipitate in the solution, a fact confirmed by Wang and Qin (2005), which makes the study of the adsorption phenomenon impossible. The solubility product $(\mathrm{Ks})$ of the metals lies between $1.2 \times 10^{-14}$ for $\left.\mathrm{CdOH}\right)_{2}$ and $5.6 \times 10^{-20}$ for $\mathrm{Cu}(\mathrm{OH})_{2}$ and should precipitate above $\mathrm{pH} \sim 8$ for a $\mathrm{M}(\mathrm{II})$ concentration of $10^{-2} \mathrm{M}$. Therefore, above this $\mathrm{pH}$, the adsorption and precipitation are responsible for the $\mathrm{M}$ (II) removal of in solutions. 
Fig. 4 Effect of sorbent dosage on the percentage removal of the metals M(II) by chitin

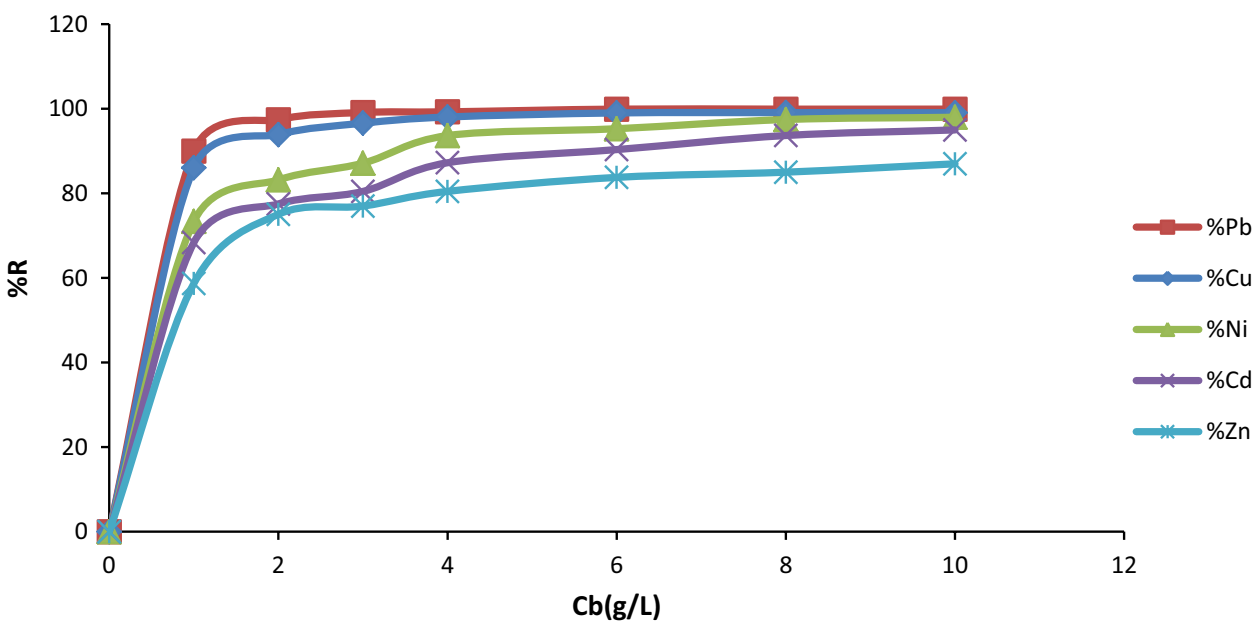

\section{Effect of biosorbent dose}

In order to optimize the quantity of chitin used to achieve maximum M(II) adsorption, we selected the following quantities: 2, 4, 6, 8, $10 \mathrm{~g} \mathrm{~L}^{-1}$ (Fig. 4) where the five curves exhibit the same shape. On the first stage, from 1 to $6 \mathrm{~g} \mathrm{~L}^{-1}$, the quantity $\mathrm{M}$ (II) adsorbed increases rapidly with raising the quantity of chitin, and this can be explained by the fact that the greater the adsorbent mass the larger the contact surface area offered to $\mathrm{M}(\mathrm{II})$ ions. On the second stage (>6 $\mathrm{g} \mathrm{L}^{-1}$ ), the amounts of $\mathrm{Cu}(\mathrm{II}), \mathrm{Cd}(\mathrm{II}), \mathrm{Zn}(\mathrm{II}), \mathrm{Ni}(\mathrm{II})$ and $\mathrm{Pb}$ (II) adsorbed remain nearly constant when the mass of chitin increases, and this results in the establishment of equilibrium between $\mathrm{M}(\mathrm{II}) /$ chitin and non-adsorbed $\mathrm{M}$ (II) in solution (Igberase and Osifo 2015; Özer et al. 2004).

\section{Effect of initial concentration of heavy metals}

The effect of initial concentration $\left(C_{0}\right)$ of $\mathrm{M}(\mathrm{II})$ on the chitin adsorption indicates that the adsorption capacity increases with increase in the concentration $C_{0}$ (Fig. 5).
This is due to the increased driving force that comes from the concentrations gradient (Salameh et al. 2015).

\section{Effect of contact time}

Figure 6 illustrates the change of adsorption capacity of different M(II) ions onto the chitin as the function of time. The curves show that the adsorption was very rapid at the first stage for all studied metals, due to well-aligned sites available for binding of $\mathrm{M}$ (II) ions under consideration, and then the adsorption slows down until equilibrium where all binding sites have been saturated; the adsorption equilibrium occurs within 30 min of all metals. It is instructive for a comparative purpose to report the values of the adsorption capacity of some adsorbents available in the literature, and Igberase (2017) have found similar results with $\mathrm{Pb}(\mathrm{II}), \mathrm{Cu}(\mathrm{II})$ and $\mathrm{Ni}(\mathrm{II})$.
Fig. 5 Effect of initial concentration of $\mathrm{M}(\mathrm{II})$ onto chitin

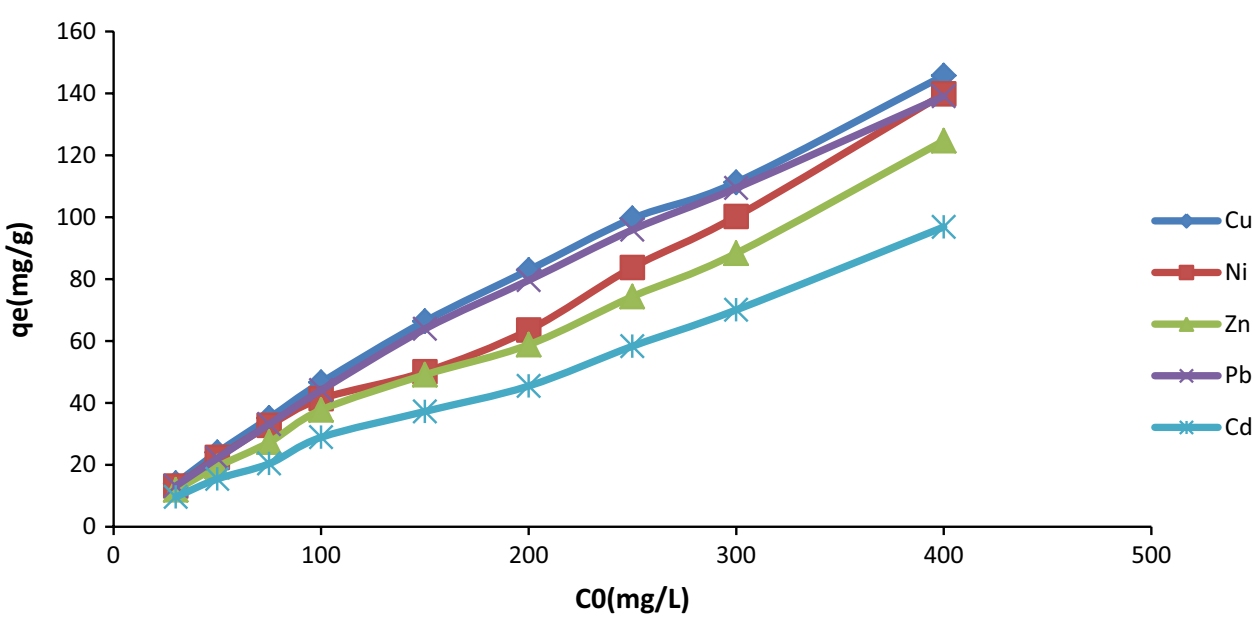




\section{Kinetic studies}

The adsorption kinetic data were analyzed using the three most common models described above. The validity of each model could be checked by the fitness of the straight lines $\left(R^{2}\right)$ values. The correlation coefficients $\left(R^{2}\right)$ show that the experimental results that follow the retention kinetics of $\mathrm{Pb}(\mathrm{II}), \mathrm{Zn}(\mathrm{II}), \mathrm{Ni}(\mathrm{II}), \mathrm{Cd}(\mathrm{II})$ and $\mathrm{Cu}(\mathrm{II})$ are better described by the pseudo-second-order model (Table 3 ). The $q_{\mathrm{e}, \text { cal }}$ values calculated from pseudo-first-order kinetic model differ appreciably from the experimental values and the coefficients $R^{2}$ of the pseudo-first-order model are small compared to unity. On the contrary, in the pseudo-second-order kinetic model the calculated $q_{\mathrm{e}, \text { cal }}$ are very close to $q_{\mathrm{e}, \mathrm{exp}}$. Further, the correlation coefficients $\left(R^{2}\right)$ are equal to 1 . By contrast, the Elovich model does not apply to all metals.
The pseudo-second-order model is suitable to describe the adsorption of toxic metals on various biosorbents (Abdeen et al. 2015; Arshad et al. 2008; Safa and Bhatti 2011).

\section{Isotherm studies}

The modeling of isotherms for $\mathrm{M}(\mathrm{II})$ adsorption onto the chitin by the above models was carried out with the linear form. The parameters of each model as well as the correlation coefficient $R^{2}$ established on the basis of the modeling curve are grouped in Table 4. For the Freundlich model, the adsorption is considered favorable when $0.1<1 / n<1$ (Karthikeyan et al. 2006; Mishra et al. 1998), whereas values less than $1 / n$ indicate a stronger interaction adsorbent/metal, while $1 / n=1$ implies linear adsorption with identical energies for all sites (Febrianto et al. 2009).
Fig. 6 Effect of contact time on the uptake of $\mathrm{Zn}(\mathrm{II}), \mathrm{Ni}(\mathrm{II})$, $\mathrm{Cu}$ (II), $\mathrm{Pb}$ (II) and $\mathrm{Cd}$ (II) by chitin

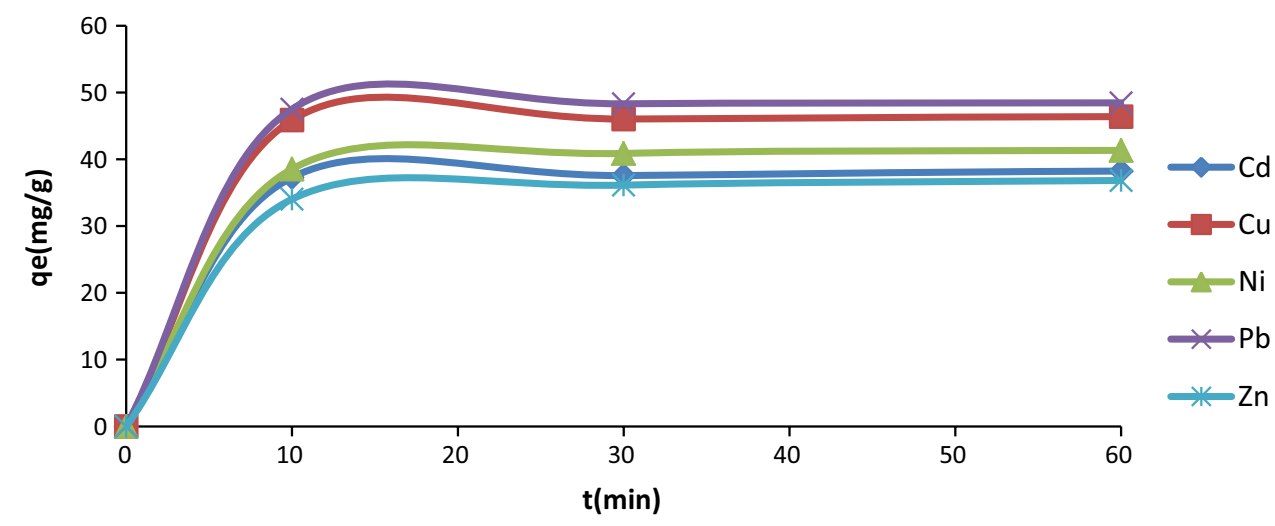

Table 3 Constants of kinetic models during heavy metals biosorption

\begin{tabular}{|c|c|c|c|c|c|c|c|c|c|}
\hline \multirow[t]{2}{*}{ Ions } & \multicolumn{3}{|c|}{ First-order model } & \multicolumn{3}{|c|}{ Second-order model } & \multicolumn{3}{|c|}{ Elovich model } \\
\hline & $R^{2}$ & $k_{1}\left(\min ^{-1}\right)$ & $q_{\exp }(\mathrm{mg} / \mathrm{g})$ & $R^{2}$ & $\begin{array}{l}k_{2} \times 10^{-3} \\
\left(\mathrm{mg} \mathrm{g}^{-1} \min ^{-1}\right)\end{array}$ & $q_{\exp }(\mathrm{mg} / \mathrm{g})$ & $\overline{R^{2}}$ & $a\left(\mathrm{mg} \mathrm{g}^{-1} \mathrm{~min}^{-1}\right)$ & $b(\mathrm{mg} / \mathrm{g})$ \\
\hline $\mathrm{Cu}(\mathrm{II})$ & 0.181 & 0.005 & 2.80 & 1 & 16 & 50 & 0.729 & 517.61 & 4 \\
\hline $\mathrm{Ni}(\mathrm{II})$ & 0.350 & 0.014 & 2.37 & 1 & 29 & 47.61 & 0.943 & 340.37 & 2.77 \\
\hline $\mathrm{Pb}(\mathrm{II})$ & 0.521 & 0.016 & 1.70 & 1 & 26 & 43.47 & 0.830 & 118.22 & 1.13 \\
\hline $\mathrm{Zn}(\mathrm{II})$ & 0.389 & 0.018 & 2.79 & 1 & 28 & 40 & 0.960 & 201.3 & 2.04 \\
\hline $\mathrm{Cd}(\mathrm{II})$ & 0.165 & 0.0052 & 2.51 & 1 & 19 & 38.46 & 0.911 & 79.91 & 0.92 \\
\hline
\end{tabular}

Table 4 Langmuir, Freundlich, Temkin and D-R models parameters for the biosorption of M(II) onto chitin

\begin{tabular}{|c|c|c|c|c|c|c|c|c|c|c|c|c|}
\hline \multirow[t]{2}{*}{ Ions } & \multicolumn{3}{|l|}{ Freundlich } & \multicolumn{3}{|l|}{ Langmuir } & \multicolumn{3}{|l|}{ Temkin } & \multicolumn{3}{|l|}{ D-R } \\
\hline & $K_{\mathrm{f}}(\mathrm{mg} / \mathrm{g})$ & $n$ & $R^{2}$ & $q_{\max }(\mathrm{mg} / \mathrm{g})$ & $K_{\mathrm{L}}(\mathrm{L} / \mathrm{mg})$ & $R^{2}$ & $\mathrm{~b}_{\mathrm{t}}(\mathrm{kJ} / \mathrm{mol})$ & $K_{\mathrm{T}}(\mathrm{L} / \mathrm{mol})$ & $R^{2}$ & $q_{\mathrm{d}}(\mathrm{mg} / \mathrm{g})$ & $B$ & $R^{2}$ \\
\hline $\mathrm{Pb}(\mathrm{II})$ & 21.32 & 2.38 & 0.92 & 142 & 0.108 & 0.952 & 61.93 & 247.52 & 0.990 & 1.01 & -100 & 0.88 \\
\hline $\mathrm{Cu}(\mathrm{II})$ & 13.46 & 2.12 & 0.949 & 166.6 & 0.057 & 0.94 & 70.83 & 81.34 & 0.979 & 1.09 & -50.48 & 0.747 \\
\hline $\mathrm{Ni}(\mathrm{II})$ & 6.68 & 1.75 & 0.977 & 138.8 & 0.028 & 0.793 & 58.53 & 100.35 & 0.994 & 1.09 & -58.03 & 0.715 \\
\hline $\mathrm{Cd}(\mathrm{II})$ & 5.47 & 1.58 & 0.999 & 100 & 0.019 & 0.715 & 46.15 & 209.08 & 0.992 & 1.07 & -100.7 & 0.623 \\
\hline $\mathrm{Zn}(\mathrm{II})$ & 3.0 & 1.53 & 0.979 & 142.85 & 0.015 & 0.724 & 46.15 & 113.77 & 0.991 & 1.1 & -47.64 & 0.633 \\
\hline
\end{tabular}


Table 5 Thermodynamic parameters for the adsorption of heavy metals onto chitin at various temperatures

\begin{tabular}{lrllll}
\hline Ion & $\Delta H^{\circ}(\mathrm{J} / \mathrm{mol})$ & $\Delta S^{\circ}(\mathrm{J} / \mathrm{mol} \mathrm{K})$ & \multicolumn{4}{l}{$-\Delta G^{\circ}(\mathrm{J} / \mathrm{mol})$} \\
\cline { 3 - 6 } & & & $293 \mathrm{~K}$ & $303 \mathrm{~K}$ & $313 \mathrm{~K}$ \\
\hline $\mathrm{Pb}(\mathrm{II})$ & 4822.22 & 25.29 & 2595.50 & 2784.27 & 2777.94 \\
$\mathrm{Cu}(\mathrm{II})$ & 7894.01 & 34.36 & 2103.51 & 2595.62 & 2808.35 \\
$\mathrm{Ni}(\mathrm{II})$ & $11,722.88$ & 47.92 & 1350.23 & 2055.50 & 2268.98 \\
$\mathrm{Cd}(\mathrm{II})$ & $12,488.32$ & 47.84 & 1350.2 & 2456.82 & 2268.98 \\
$\mathrm{Zn}(\mathrm{II})$ & $12,621.32$ & 44.01 & 125.04 & 1216.17 & 838.75 \\
\hline
\end{tabular}

The Freundlich model is efficient for analyzing the data of $\mathrm{M}(\mathrm{II})$ adsorption $\left(R^{2} \geq 0.92\right)$. Biological surfaces are expected to have heterogeneous energies for adsorbing metals, and therefore a good fit was expected (Sağ and Aktay 2000).

The Langmuir model was successfully used for analyzing the experimental data of $\mathrm{Pb}(\mathrm{II})$ and $\mathrm{Cu}$ (II) onto chitin $\left(R^{2} \geq 0.92\right)$, but becomes invalid for $\mathrm{Cd}(\mathrm{II}), \mathrm{Ni}(\mathrm{II})$ and $\mathrm{Zn}(\mathrm{II})$. By contrast, the adsorption data of all ions onto the chitin agree with the Temkin model $\left(R^{2} \geq 0.92\right)$ (Igberase 2017).

\section{Thermodynamic studies}

The results of thermodynamic studies, gathered in Table 5, indicate a decrease in the free energy $\Delta G^{\circ}$, thus confirming a spontaneous nature of the M(II) adsorption under the experimental conditions (Singh and Pant 2004). The positive enthalpy $\Delta \mathrm{H}$ suggests endothermic adsorption (Atia et al. 2008; Chegrouche et al. 2009), while the positive value of $\Delta S$ confirms the increased randomness at the solid-liquid interface during M(II) adsorption (Kumar 2011). The necessity of large heats to remove the metals ions from the solution makes the adsorption endothermic (Al-Sou'od 2012).

This work is continuing, and as perspective, the models developed by Fulazzaky et al. $(2017,2018)$ in fixed bed column for the determination of external, internal and global mass transfer factors will be undertaken very soon.

\section{Conclusion}

The main objective of the present contribution was focused on the development of marine biomass namely the crab shells which were used as natural supports for the retention of five heavy metals: copper, zinc, cadmium, nickel and lead in aqueous solution. It has been demonstrated that the mechanism of metal adsorption by chitin is dependent on the initial $\mathrm{pH}$ of the solution. Thus, at acidic $\mathrm{pHs}$, the competition between protons and $\mathrm{M}(\mathrm{II})$ ion decreases the adsorption performance of chitin, whereas for $\mathrm{pH}$ greater than 7, a saturation of the adsorption capacity is observed.
The precipitation to hydroxides $\mathrm{M}(\mathrm{OH})_{2}$ also accounts for this saturation because of the low-solubility products. An increase in the metal concentration and the mass of chitin favors the adsorption process. The adsorption isotherms of the five toxic metals by chitin is satisfactorily described by the Freundlich and Temkin models throughout the investigated concentrations for all metals, whereas the Langmuir model does not fit suitably the experimental data for $\mathrm{Ni}, \mathrm{Zn}$ and $\mathrm{Cd}$ ions. The spontaneous and endothermic adsorptions of the metals were evidenced from the negative free energy $\left(\Delta G^{\circ}\right)$ and positive enthalpy $\left(\Delta H^{\circ}\right)$.

Acknowledgements The authors thank the LEPCMAE laboratory team, as well as the Dean of the Faculty of Chemistry (USTHB Algiers) for their support. The authors are also grateful to Dr B. Belhamdi for his technical assistance.

\section{Compliance with ethical standards}

Conflict of interest On behalf of all authors, the corresponding author states that there is no conflict of interest.

Open Access This article is distributed under the terms of the Creative Commons Attribution 4.0 International License (http://creativeco mmons.org/licenses/by/4.0/), which permits unrestricted use, distribution, and reproduction in any medium, provided you give appropriate credit to the original author(s) and the source, provide a link to the Creative Commons license, and indicate if changes were made.

\section{References}

Abdeen Z, Mohammad S, Mahmoud M (2015) Adsorption of Mn(II) ion on polyvinyl alcohol/chitosan dry blending from aqueous solution. Environ Nanotechnol Monit Manag 3:1-9

Abolhasani J, Behbahani M (2015) Application of 1-(2-pyridylazo)2-naphthol-modified nanoporous silica as a technique in simultaneous trace monitoring and removal of toxic heavy metals in food and water samples. Environ Monit Assess 187:4176

Ali I, Ateeg AA (2015) Study of soil pollutants in Omdurman industrial area, Sudan, using X-ray fluorescence technique. Int J Environ Res 9:291-294

Al-Sou'od K (2012) Adsorption isotherm studies of chromium (VI) from aqueous solutions using Jordanian pottery materials. APCBEE Procedia 1:116-125

Arshad M, Zafar MN, Younis S, Nadeem R (2008) The use of Neem biomass for the biosorption of zinc from aqueous solutions. $\mathrm{J}$ Hazard Mater 157:534-540. https://doi.org/10.1016/j.jhazm at.2008.01.017

Atia AA, Donia AM, Yousif AM (2008) Removal of some hazardous heavy metals from aqueous solution using magnetic chelating resin with iminodiacetate functionality. Sep Purif Technol 61:348-357

Behbahani M, Tapeh NAG, Mahyari M, Pourali AR, Amin BG, Shaabani A (2014) Monitoring of trace amounts of heavy metals in different food and water samples by flame atomic absorption spectrophotometer after preconcentration by amine-functionalized graphene nanosheet. Environ Monit Assess 186:7245-7257. https ://doi.org/10.1007/s10661-014-3924-1 
Behbahani M, Aliakbari A, Amini MM, Behbahani AS, Omidi F (2015) Synthesis and characterization of diphenylcarbazide-siliceous mesocellular foam and its application as a novel mesoporous sorbent for preconcentration and trace detection of copper and cadmium ions. RSC Adv. https://doi.org/10.1039/c5ra10240e

Bouberka Z, Kacha S, Kameche M, Elmaleh S, Derriche Z (2005) Sorption study of an acid dye from an aqueous solutions using modified clays. J Hazard Mater 119:117-124. https://doi. org/10.1016/j.jhazmat.2004.11.026

Chegrouche S, Mellah A, Barkat M (2009) Removal of strontium from aqueous solutions by adsorption onto activated carbon: kinetic and thermodynamic studies. Desalination 235:306-318

Chen X (2015) Modeling of experimental adsorption isotherm data. Information. https://doi.org/10.3390/info6010014

Copat C, Maggiore R, Arena G, Lanzafame S, Fallico R, Sciacca S, Ferrante M (2012) Evaluation of a temporal trend heavy metals contamination in Posidonia oceanica (L.) Delile, (1813) along the western coastline of Sicily (Italy). J Environ Monit 14:187-192. https://doi.org/10.1039/c1em10575b

Dąbrowski A, Hubicki Z, Podkościelny P, Robens E (2004) Selective removal of the heavy metal ions from waters and industrial wastewaters by ion-exchange method. Chemosphere 56:91-106. https ://doi.org/10.1016/j.chemosphere.2004.03.006

Deng L, Zhang Y, Qin J, Wang X, Zhu X (2009) Biosorption of $\mathrm{Cr}(\mathrm{VI})$ from aqueous solutions by nonliving green algae $\mathrm{Clad}$ ophora albida. Minerals Engineering 22:372-377. https://doi. org/10.1016/j.mineng.2008.10.006

Erhayem M, Al-Tohami F, Mohamed R, Ahmida K (2015) Isotherm, kinetic and thermodynamic studies for the sorption of mercury (II) onto activated carbon from Rosmarinus officinalis leaves. Am J Anal Chem. https://doi.org/10.4236/ajac.2015.61001

Esalah JO, Weber ME, Vera JH (2000) Removal of lead, cadmium and zinc from aqueous solutions by precipitation with sodium Di-(n-octyl) phosphinate. Can J Chem Eng 78:948-954. https:// doi.org/10.1002/cjce.5450780512

Febrianto J, Kosasih AN, Sunarso J, Ju Y-H, Indraswati N, Ismadji S (2009) Equilibrium and kinetic studies in adsorption of heavy metals using biosorbent: a summary of recent studies. J Hazard Mater 162:616-645. https://doi.org/10.1016/j.jhazmat.2008.06.042

Fulazzaky MA (2011) Determining the resistance of mass transfer for adsorption of the surfactants onto granular activated carbons from hydrodynamic column. Chem Eng J 166:832-840

Fulazzaky MA, Khamidun MH, Omar R (2013) Understanding of mass transfer resistance for the adsorption of solute onto porous material from the modified mass transfer factor models. Chem Eng $\mathbf{J}$ 228:1023-1029

Fulazzaky MA, Abdullah S, Salim MR (2015) Fundamentals of mass transfer and kinetics for biosorption of oil and grease from agrofood industrial effluent by Serratia marcescens SA30. RSC Adv 5:104666-104673

Fulazzaky MA, Nuid M, Aris A, Muda K (2017) Kinetics and mass transfer studies on the biosorption of organic matter from palm oil mill effluent by aerobic granules before and after the addition of Serratia marcescens SA30 in a sequencing batch reactor. Process Saf Environ Prot 107:259-268

Fulazzaky MA, Nuid M, Aris A, Muda K (2018) Mass transfer kinetics of biosorption of nitrogenous matter from palm oil mill effluent by aerobic granules in sequencing batch reactor. Environ Technol 39:2151-2161

Gupta VK, Gupta M, Sharma S (2001) Process development for the removal of lead and chromium from aqueous solutions using red mud-an aluminium industry waste. Water Res 35:1125-1134. https://doi.org/10.1016/S0043-1354(00)00389-4

Hafiane A, Lemordant D, Dhahbi M (2000) Removal of hexavalent chromium by nanofiltration. Desalination 130:305-312. https:// doi.org/10.1016/S0011-9164(00)00094-1
Hutson ND, Yang RT (1997) Theoretical basis for the Dubinin-Radushkevitch (D-R) adsorption isotherm equation. Adsorption 3:189195. https://doi.org/10.1007/bf01650130

Igberase $\mathrm{E}$ (2017) The adsorption of $\mathrm{Pb}, \mathrm{Zn}, \mathrm{Cu}, \mathrm{Ni}$, and $\mathrm{Cd}$ by modified ligand in a single component aqueous solution: equilibrium, kinetic, thermodynamic, and desorption studies. Int J Anal Chem. https://doi.org/10.1155/2017/6150209

Igberase E, Osifo P (2015) Equilibrium, kinetic, thermodynamic and desorption studies of cadmium and lead by polyaniline grafted cross-linked chitosan beads from aqueous solution. J Ind Eng Chem 26:340-347. https://doi.org/10.1016/j.jiec.2014.12.007

Izquierdo M, Gabaldón C, Marzal P (2014) Modeling of the effect of EDTA on copper(II) biosorption onto Posidonia oceanica waste in batch and fixed-bed systems. J Taiwan Inst Chem Eng 45:665673. https://doi.org/10.1016/j.jtice.2013.08.001

Jaafarzadeh N, Mengelizadeh N, Takdastan A, Heidari-Farsani M, Niknam N (2014) Adsorption of Zn (II) from aqueous solution by using chitin extraction from crustaceous shell. J Adv Environ Health Res 2(2):110-119. https://doi.org/10.22102/jaehr .2014.40151

Jaafarzadeh $\mathrm{N}$ et al (2015) Biosorption of heavy metals from aqueous solutions onto chitin. Int J Environ Health Eng. https://doi. org/10.4103/2277-9183.153992

Kang KC, Kim SS, Choi JW, Kwon SH (2008) Sorption of Cu2+ and $\mathrm{Cd} 2+$ onto acid- and base-pretreated granular activated carbon and activated carbon fiber samples. J Ind Eng Chem 14:131-135. https://doi.org/10.1016/j.jiec.2007.08.007

Karthikeyan G, Andal NM, Anbalagan K (2005) Adsorption studies of iron(III) on chitin. J Chem Sci 117:663-672. https://doi. org/10.1007/bf02708296

Karthikeyan T, Rajgopal S, Miranda L (2006) Chromium (VI) adsorption from aqueous solution by Hevea brasiliensis sawdust activated carbon. J Hazard Mater 124:192-199

Khezami L, Capart R (2005) Removal of chromium(VI) from aqueous solution by activated carbons: kinetic and equilibrium studies. J Hazard Mater 123(1-3):223-231. https://doi.org/10.1016/j.jhazm at.2005.04.012

Kumar U (2011) Thermodynamics of the adsorption of Cd (II) from aqueous solution on NCRH cylinder. Int J Environ Sci Dev 2:334

Kumirska J, Czerwicka M, Kaczyński Z, Bychowska A, Brzozowski K, Thöming J, Stepnowski P (2010) Application of spectroscopic methods for structural analysis of chitin and chitosan. Mar Drugs 8:1567-1636. https://doi.org/10.3390/md8051567

Lima E, Adebayo M, Machado F, Adebayo AM, Machado MF, Lima CE (2015) Kinetic and equilibrium models of adsorption. https:// doi.org/10.1007/978-3-319-18875-1_3

Liu Y, Liu Y-J (2008) Biosorption isotherms, kinetics and thermodynamics. Sep Purif Technol 61:229-242

Madala S, Nadavala SK, Vudagandla S, Boddu VM, Abburi K (2017) Equilibrium, kinetics and thermodynamics of cadmium (II) biosorption on to composite chitosan biosorbent. Arab J Chem 10:S1883-S1893. https://doi.org/10.1016/j.arabjc.2013.07.017

Malairajan S (2011) Removal of lead(II) and cadmium(II) ions from wastewater using activated biocarbon. Sci Asia. https://doi. org/10.2306/scienceasia1513-1874.2011.37.115

McKay G, Ho Y, Ng J (1999) Biosorption of copper from waste waters: a review. Sep Purif Methods 28:87-125

Mishra SP, Tiwari D, Dubey RS, Mishra M (1998) Biosorptive behaviour of casein for $\mathrm{Zn} 2+, \mathrm{Hg} 2+$ and $\mathrm{Cr} 3+$ : effects of physicochemical treatments. Bioresour Technol 63:1-5. https://doi. org/10.1016/S0960-8524(97)00110-7

Mohan K, Syed-Shafi S (2013) Removal of cadmium from the aqueous solution using chitin/polyethylene glycol binary blend. Der Pharma Lett 5:62-69

Özcan A, Özcan AS, Tunali S, Akar T, Kiran I (2005) Determination of the equilibrium, kinetic and thermodynamic parameters

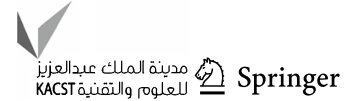


of adsorption of copper(II) ions onto seeds of Capsicum annuum. J Hazard Mater 124:200-208. https://doi.org/10.1016/j.jhazm at.2005.05.007

Özer A, Özer D, Özer A (2004) The adsorption of copper(II) ions on to dehydrated wheat bran (DWB): determination of the equilibrium and thermodynamic parameters. Process Biochem 39:2183-2191. https://doi.org/10.1016/j.procbio.2003.11.008

Pagnanelli F, Mainelli S, De Angelis S, Toro L (2005) Biosorption of protons and heavy metals onto olive pomace: modelling of competition effects. Water Res 39:1639-1651

Pérez-Marín AB, Zapata VM, Ortuño JF, Aguilar M, Sáez J, Lloréns M (2007) Removal of cadmium from aqueous solutions by adsorption onto orange waste. J Hazard Mater 139:122-131. https://doi. org/10.1016/j.jhazmat.2006.06.008

Rashid J, Barakat M, Alghamdi M (2014) Adsorption of chromium (VI) from wastewater by anion exchange resin. J Adv Catal Sci Technol. https://doi.org/10.15379/2408-9834.2014.01.02.04

Rasti H, Parivar K, Baharara J, Iranshahi M, Namvar F (2017) Chitin from the mollusc chiton: extraction, characterization and chitosan preparation. Iran J Pharm Res IJPR 16:366-379

Safa Y, Bhatti HN (2011) Kinetic and thermodynamic modeling for the removal of Direct Red-31 and Direct Orange-26 dyes from aqueous solutions by rice husk. Desalination 272:313-322

Sağ Y, Aktay Y (2000) Mass transfer and equilibrium studies for the sorption of chromium ions onto chitin. Process Biochem 36:157-173

Salameh Y, Albadarin AB, Allen S, Walker G, Ahmad MNM (2015) Arsenic(III, V) adsorption onto charred dolomite: charring optimization and batch studies. Chem Eng J 259:663-671. https://doi. org/10.1016/j.cej.2014.08.038

Salem NM, Awwad AM, Al-Dujaili AH (2012) Biosorption of Pb(II), $\mathrm{Zn}(\mathrm{II})$, and $\mathrm{Cd}(\mathrm{II})$ from aqueous solutions by (Eriobotrya japonica) Loquat Bark. Int J Environ Prot 2:1

Samiey B, Ashoori F (2012) Adsorptive removal of methylene blue by agar: effects of $\mathrm{NaCl}$ and ethanol. Chem Central J. https://doi. org/10.1186/1752-153x-6-14
Sar1 A, Tuzen M (2008) Biosorption of total chromium from aqueous solution by red algae (Ceramium virgatum): equilibrium, kinetic and thermodynamic studies. J Hazard Mater 160:349-355. https ://doi.org/10.1016/j.jhazmat.2008.03.005

Sawada A, K-i Mori, Tanaka S, Fukushima M, Tatsumi K (2004) Removal of $\mathrm{Cr}(\mathrm{VI})$ from contaminated soil by electrokinetic remediation. Waste Manag 24:483-490. https://doi.org/10.1016/ S0956-053X(03)00133-8

Singh TS, Pant K (2004) Equilibrium, kinetics and thermodynamic studies for adsorption of As (III) on activated alumina. Sep Purif Technol 36:139-147

Sofiane B, Sofia KS (2015) Biosorption of heavy metals by chitin and the chitosan. Dev Pharm Chem 7:54-63

Vilar VJP, Botelho CMS, Boaventura RAR (2008) Copper removal by algae Gelidium, agar extraction algal waste and granulated algal waste: kinetics and equilibrium. Bioresour Technol 99:750-762. https://doi.org/10.1016/j.biortech.2007.01.042

Volesky B (1990) Removal and recovery of heavy metals by biosorption. In: Biosorption of heavy metals, pp 7-43

Wang X-S, Qin Y (2005) Equilibrium sorption isotherms for of $\mathrm{Cu} 2+$ on rice bran. Process Biochem 40:677-680. https://doi. org/10.1016/j.procbio.2004.01.043

Xiong C (2010) Adsorption of cadmium (II) by chitin. J Chem Soc Pak 32:429-435

Yue Z, Bender SE, Wang J, Economy J (2009) Removal of chromium $\mathrm{Cr}(\mathrm{VI})$ by low-cost chemically activated carbon materials from water. J Hazard Mater 166:74-78. https://doi.org/10.1016/j.jhazm at.2008.10.125

Publisher's Note Springer Nature remains neutral with regard to jurisdictional claims in published maps and institutional affiliations. 